\title{
Evaluation of thermal energy consumption in broiler farms and saving strategies
}

[Avaliação do consume de energia térmica em granjas de frango e estratégias de economia]

\author{
A. Jahedi ${ }^{1}$, A. Zarei ${ }^{2 *}$ \\ ${ }^{1}$ Department of Animal Science, Ghaem Shahr Branch, Islamic Azad University, Ghaem Shahr, Iran. \\ ${ }^{2}$ Department of Animal Science, Karaj Branch, Islamic Azad University, Karaj, Iran.
}

\begin{abstract}
The aim of this study was to evaluate thermal energy consumption in broiler farms and provide solutions to reduce it. This study was performed with a completely randomized design under 4 climatic conditions, including Ardabil (cold climate representative), Khuzestan (warm climate representative), Isfahan (dry climate representative) and Guilan (temperate climate representative) in 4 replicates (4 broiler farms in each climate) and with 5 repetitions (5 periods of breeding per unit) and a capacity of 492,700, Ross 308 broiler in each breeding period. According to the results, in all climates, the proposed solutions to save thermal energy were able to create a significant difference $(P<0.05)$. The experimental results also showed that the difference in thermal energy consumption in cold and dry climates wasmuch higher than in temperate and warm climates $(P<0.05)$. Overall, the results of the present study show that, by optimizing andmodernizing construction equipment in broiler farms, thermal energy losses can be reduced in all climatic conditions.
\end{abstract}

Keywords: thermal energy, climate, solution, broiler farming

\section{RESUMO}

O objetivo do presente estudo foi avaliar o consumo de energia térmica em granjas de frangos de corte e fornecer soluções para reduzi-lo. Este estudo foi realizado com um desenho inteiramente casualizado em 4 condições climáticas, incluindo Ardabil (representante do clima frio), Khuzestan (representante do clima quente), Isfahan (representante do clima seco) e Guilan (representante do clima temperado) em 4 réplicas (4 granjas de frangos em cada clima), com 5 repetições (5 períodos de criação por unidade) $e$ capacidade de 492.700 frangos Ross 308 em cada período de criação. De acordo com os resultados, em todos os climas, as soluções propostas para economizar energia térmica criaram diferença significativa $(P<0,05)$. Os resultados experimentais também mostraram que a diferença no consumo de energia térmica em climas frios e secos foi muito maior do que em climas temperados e quentes $(P<0,05)$. De forma geral, os resultados do presente estudo mostram que, com a otimização e modernização dos equipamentos de construção em granjas de frangos, as perdas de energia térmica podem ser reduzidas em todas as condições climáticas.

Palavras-chave: energia térmica, clima, solução, avicultura

\section{INTRODUCTION}

In many countries around the world, optimizing energy consumption is one of the main goals of the industry and agriculture. Therefore, many efforts have beenmade in these countries to reduce energy demand and make optimal use of energy resources (Poorghasemi et al., 2017; Ali

Recebido em 20 de maio de 2020

Aceito em 21 de julho de 2020

*Autor para correspondência (corresponding author)

E-mail: a-zarei@kiau.ac.ir et al., 2013). Saving energy consumption in any economic activity is considered one of the main factors that reduces costs and as a result increases income, which is why it is so important (Omid et al., 2011; Deribe and Taye, 2014).

The poultry industry is no exception, and the strategies implemented in this industry have greatly helped to save energy consumption in this area. The strategic value of poultry products 
is important because of the supply of protein. For this reason, great efforts must bemade to increase the efficiency and reduce the costs of this industry (Barott et al., 1938; Najafi et al., 2012). The poultry industry is one of the energyintensive and sensitive industries, such that decrease or increase in a factor such as temperature has a significant effect on poultry production and losses. Animals need a number of factors to demonstrate their genetic potential, which are part of the environment.

One of the most important factors is the suitability of poultry farms and facilities for their needs. In order for birds to survive, and for the health, growth and vitality of poultry, suitable air supply, temperature, humidity and lighting are essential, and in fact, the most important goal of the construction of poultry houses is to provide these conditions. In this regard, in order to provide suitable conditions in the houses, it is necessary to spend energy and mainly fossil energy to heat the houses. The accuracy of energy consumption and automation have a very high priority because the industry ranks second in fuel consumption after the transportation system (Singh et al., 2002; Gholami et al., 2020).

The importance of energy saving in production of animal products is great due to climate change and rising energy costs. Studies show that the main energy consumption in broiler farms includes heat and electricity (direct) and food (indirect). Today, the highest cost in poultry farms is the cost of grain (Toklu et al., 2010). In direct energy consumption in poultry farming, the main part is the consumption of fuel, and the proportion of electricity as compared with fuel is very small. Although the share of direct energy is less expensive than that of grain, the ratio of fuel and electricity to grain is expected to increase in the future (Yusef and Malomo, 2007; Singh et al., 2004). Rising energy prices, especially oil and gas, have led poultry farmers to modify buildings and poultry equipment to reduce the added costs (Zhou et al., 2008).

According to most research in poultry science, factors contributing to the rapid growth of broilers for commercial chickens have been identified as one of the important factors in economic profit and for this reason research has focused on rapid weight gain, reduced feed conversion ratio, and increased carcass yields and less attention has been paid to new subjects such as the optimal use of energy resources and saving it, which is one of themain factors in the economic benefits of poultry farming. According to the above, the present study aims to explore the current situation of meat poultry farms in terms of thermal energy consumption in four different climates (cold, hot, dry and temperate) and to provide various strategies to reduce energy consumption in the poultry industry.

\section{MATERIALS AND METHODS}

This study was performed as a completely randomized design in 4 locations with different climates: Ardabil (cold climate representative), Khuzestan (warm climate representative), Isfahan (dry climate representative) and Guilan (temperate climate representative) in four treatments (four broiler farms in each climate), with five repetitions (five periods of rearing per unit) and with a capacity of 492,700 308 Ross broiler in each rearing period. The climatic characteristics of the experimental climates are presented in Tables 1, 2, 3 and 4.

Data collection was performed by visiting the relevant units and recording information. Initially, to assess the condition of the houses, we estimated the heat transfer coefficient of the external walls, including the walls, floor and roof of the houses. For this purpose, thematerial of the components and the estimation of heat transfer coefficient of each of the external walls are assessed according to climatic characteristics. In order to measure the temperature of the houses, in addition to data sampling from direct hot air blowers, thermal imaging was performed in different parts of the houses. In thermal images, light colors indicate higher surface temperatures, and dark colors indicate lower temperatures. In addition, a graduated tape was placed on the right side of the thermal image, so that the temperature of each surface could be easily seen. Figure 1 shows a thermal image demonstrating the surface temperature of the walls, roof, and floor of the houses. 
Table 1. Climatic conditions in Ardabil (Adapted from: http://www.irimo.ir)

\begin{tabular}{|c|c|c|c|c|c|c|c|c|c|c|c|c|}
\hline $\begin{array}{l}\bar{\equiv} \\
\sum_{0}^{0}\end{array}$ & $\begin{array}{l}\vec{\Xi} \\
\stackrel{\Xi}{\Xi} \\
\text { ज्ञ }\end{array}$ & $\begin{array}{l}\vec{E} \\
\vec{E} \\
\text { D. } \\
\text { D. }\end{array}$ & $\begin{array}{l}\frac{\pi}{0} \\
\text { ¿ँّ }\end{array}$ & $\overline{\bar{z}}$ & $\sum^{\vec{\Xi}}$ & $\stackrel{\Xi}{\Xi}$ & 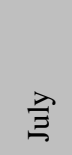 & $\begin{array}{l}\vec{v} \\
\overrightarrow{00} \\
\vec{z}\end{array}$ & $\begin{array}{l}\dot{\bar{D}} \\
\text { है } \\
\text { हैँ } \\
\text { चे }\end{array}$ & $\begin{array}{l}\bar{\delta} \\
\stackrel{0}{0} \\
0\end{array}$ & $\begin{array}{l}\dot{\bar{\delta}} \\
\ddot{\Xi} \\
\overline{0} \\
\overrightarrow{0} \\
z\end{array}$ & 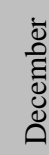 \\
\hline $\begin{array}{l}\text { Average ofmaximum } \\
\text { temperature }\left({ }^{\circ} \mathrm{C}\right)\end{array}$ & 3 & 4 & 11 & 18 & 20 & 23 & 24 & 26 & 22 & 18 & 10 & 5 \\
\hline $\begin{array}{l}\text { Average ofminimum } \\
\text { temperature }\left({ }^{\circ} \mathrm{C}\right)\end{array}$ & -9 & -10 & -4 & 3 & 5 & 8 & 12 & 13 & 10 & 5 & 0 & -2 \\
\hline Average humidity (\%) & 70 & 63 & 50 & 35 & 25 & 20 & 20 & 25 & 25 & 30 & 35 & 65 \\
\hline $\begin{array}{l}\text { Number of days with } \\
\text { clear skies }\end{array}$ & 13 & 14 & 14 & 13 & 22 & 26 & 24 & 23 & 27 & 21 & 17 & 13 \\
\hline $\begin{array}{l}\text { Number of semi-cloudy } \\
\text { days }\end{array}$ & 9 & 8 & 9 & 10 & 3 & 1 & 4 & 5 & 1 & 6 & 9 & 10 \\
\hline $\begin{array}{l}\text { The number of } \\
\text { completely cloudy days }\end{array}$ & 8 & 8 & 7 & 7 & 5 & 3 & 2 & 2 & 2 & 3 & 4 & 7 \\
\hline
\end{tabular}

Table 2. Climatic conditions in Khouzestan (Adapted from: http://www.irimo.ir)

\begin{tabular}{|c|c|c|c|c|c|c|c|c|c|c|c|c|}
\hline 吾 & 怘 & $\begin{array}{l}\vec{E} \\
\overrightarrow{0} \\
\frac{0}{0} \\
\text { i. }\end{array}$ & 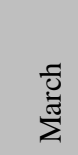 & $\overline{\frac{2}{2}}$ & $\vec{\Xi}$ & $\stackrel{\varrho}{\Xi}$ & $\stackrel{\gtrsim}{\Xi}$ & 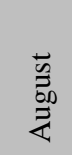 & 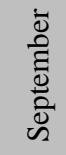 & $\begin{array}{l}\dot{\bar{D}} \\
\stackrel{0}{0} \\
0\end{array}$ & $\begin{array}{l}\dot{\bar{D}} \\
\stackrel{0}{0} \\
\overline{0} \\
\dot{0}\end{array}$ & 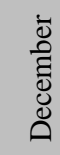 \\
\hline $\begin{array}{l}\text { Average ofmaximum } \\
\text { temperature }\left({ }^{\circ} \mathrm{C}\right)\end{array}$ & 17.5 & 20 & 24.5 & 33 & 40 & 44.5 & 46.5 & 46 & 42 & 35 & 27 & 20 \\
\hline $\begin{array}{l}\text { Average ofminimum } \\
\text { temperature }\left({ }^{\circ} \mathrm{C}\right)\end{array}$ & 9.5 & 10 & 13 & 20 & 25 & 28 & 31 & 31 & 26 & 21 & 14.5 & 11 \\
\hline Average humidity (\%) & 70 & 63 & 50 & 35 & 25 & 20 & 20 & 25 & 25 & 30 & 35 & 65 \\
\hline $\begin{array}{l}\text { Number of days with } \\
\text { clear skies }\end{array}$ & 14 & 15 & 18 & 17 & 27 & 29 & 30 & 29 & 29 & 24 & 18 & 15 \\
\hline $\begin{array}{l}\text { Number of semi- } \\
\text { cloudy days }\end{array}$ & 9 & 8 & 9 & 10 & 3 & 1 & 1 & 2 & 1 & 6 & 9 & 10 \\
\hline $\begin{array}{l}\text { The number of } \\
\text { completely cloudy } \\
\text { days }\end{array}$ & 8 & 5 & 4 & 3 & 1 & 0 & 0 & 0 & 0 & 1 & 3 & 6 \\
\hline
\end{tabular}

Table 3. Climatic conditions in Isfahan (Adapted from: http://www.irimo.ir)

\begin{tabular}{|c|c|c|c|c|c|c|c|c|c|c|c|c|}
\hline $\begin{array}{l}\overline{0} \\
\stackrel{\Xi}{0}\end{array}$ & 胥 & 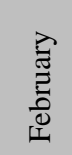 & 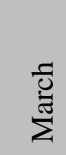 & $\overline{\bar{z}}$ & $\sum_{i}^{\vec{I}}$ & $\stackrel{\varrho}{\Xi}$ & 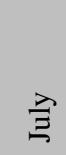 & 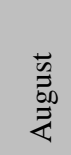 & 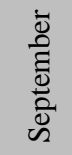 & $\begin{array}{l}\overline{0} \\
\frac{0}{0} \\
\overline{0}\end{array}$ & $\begin{array}{l}\bar{\Xi} \\
\text { है } \\
\text { ठठ } \\
z\end{array}$ & 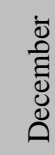 \\
\hline $\begin{array}{l}\text { Average ofmaximum } \\
\text { temperature }\left({ }^{\circ} \mathrm{C}\right)\end{array}$ & 9 & 12 & 17 & 24 & 29 & 35 & 38 & 36 & 32 & 25 & 15 & 11 \\
\hline $\begin{array}{l}\text { Average ofminimum } \\
\text { temperature }\left({ }^{\circ} \mathrm{C}\right)\end{array}$ & -3 & -1 & 3 & 10 & 13 & 18 & 21 & 19 & 16 & 9 & 5 & -1 \\
\hline Average humidity (\%) & 45 & 40 & 35 & 35 & 25 & 20 & 20 & 25 & 25 & 30 & 35 & 45 \\
\hline $\begin{array}{l}\text { Number of days with } \\
\text { clear skies }\end{array}$ & 13 & 14 & 14 & 13 & 26 & 28 & 24 & 23 & 27 & 21 & 19 & 15 \\
\hline $\begin{array}{l}\text { Number of semi- } \\
\text { cloudy days }\end{array}$ & 9 & 8 & 9 & 10 & 3 & 1 & 4 & 5 & 1 & 6 & 7 & 8 \\
\hline $\begin{array}{l}\text { The number of } \\
\text { completely cloudy } \\
\text { days }\end{array}$ & 8 & 8 & 7 & 7 & 5 & 3 & 2 & 2 & 2 & 3 & 4 & 7 \\
\hline
\end{tabular}


Table 4. Climatic conditions in Guilan (Adapted from: http://www.irimo.ir)

\begin{tabular}{|c|c|c|c|c|c|c|c|c|c|c|c|c|}
\hline $\begin{array}{l}\bar{\Xi} \\
\sum_{0}^{0} \\
\Sigma\end{array}$ & 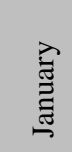 & 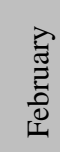 & 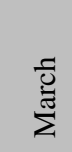 & $\overline{\bar{z}}$ & $\stackrel{\vec{\Xi}}{\Sigma}$ & $\stackrel{\Xi}{\Xi}$ & 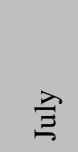 & $\begin{array}{l}\overrightarrow{\vec{a}} \\
\overrightarrow{00} \\
\vec{z}\end{array}$ & 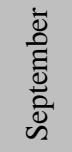 & 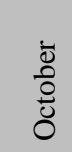 & $\begin{array}{l}\dot{\bar{D}} \\
\text { है } \\
\text { Dे } \\
\text { Z }\end{array}$ & 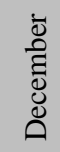 \\
\hline $\begin{array}{l}\text { Average ofmaximum } \\
\text { temperature }\left({ }^{\circ} \mathrm{C}\right)\end{array}$ & 14 & 12 & 15 & 18 & 27 & 31 & 30 & 30 & 25 & 23 & 16 & 14 \\
\hline $\begin{array}{l}\text { Average ofminimum } \\
\text { temperature }\left({ }^{\circ} \mathrm{C}\right)\end{array}$ & 5 & 6 & 7 & 10 & 18 & 22 & 22 & 21 & 18 & 16 & 11 & 9 \\
\hline Average humidity (\%) & 82 & 88 & 85 & 82 & 78 & 70 & 80 & 84 & 86 & 88 & 89 & 86 \\
\hline $\begin{array}{l}\text { Number of days with clear } \\
\text { skies }\end{array}$ & 132 & 88 & 114 & 149 & 207 & 332 & 247 & 205 & 92 & 116 & 58 & 72 \\
\hline $\begin{array}{l}\text { Number of semi-cloudy } \\
\text { days }\end{array}$ & 4 & 5 & 5 & 5 & 4 & 2 & 3 & 4 & & & 6 & 6 \\
\hline $\begin{array}{l}\text { The number of completely } \\
\text { cloudy days }\end{array}$ & 7 & 15 & 18 & 13 & 11 & 6 & 10 & 10 & 18 & 15 & 18 & 19 \\
\hline
\end{tabular}
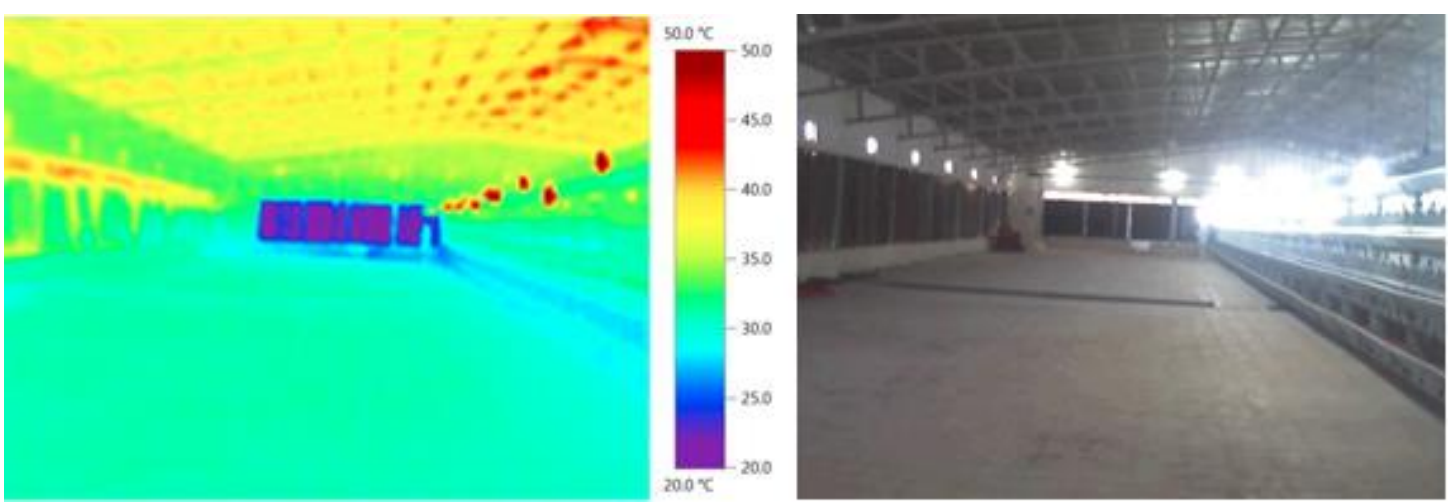

Figure 1. Thermal image and appearance of the initial 35meters of the houses.

In order to measure loss of thermal energy, the calculations were based on the information collected from the location and the climate model of the region. Air temperature, humidity, lighting and lamps used, efficiency of heating system, and thermal and cooling needs of the house were among this information. The operation times of the house were considered 5 times a year with the house at full capacity. Since each living organism produces some heat due to chemical interactions within the body, the heat generated by the chicken's body was calculated to program the smart control system to control the indoor air temperature.

This amount of heat varies depending on the species, body weight and age. For chickens on broiler farms, this figure is shown in Table 5. The amount of heat obtained for each 1000 chicks is presented in Table 5. The heat produced by the chicken body in each period of breeding was calculated based on the pattern of five rearing periods per year. These calculations are presented in Table 6.

Table 5. Heat production rate from chicken metabolism

\begin{tabular}{cc}
\hline Chicken's age (week) & $\begin{array}{c}\text { Heat production amount } \\
\text { from 1000 chickens } \\
\text { (kilowatts) }\end{array}$ \\
\hline 1 & 0.4 \\
2 & 1.1 \\
3 & 2.3 \\
4 & 3.9 \\
5 & 5.5 \\
6 & 7.7 \\
7 & 9.9 \\
\hline
\end{tabular}

Also, the indoor air quality, including temperature, humidity, lighting, and ammonia and carbonmonoxide levels, was measured in different locations. Then, with the information related to heating equipment, the thermal efficiency of thermal equipment was calculated. 
According to the National Building Regulations Standard and based on the measured conditions as well as the architectural information, the heat load coefficients of the houses were calculated as shown in Table 7. The calculation method of this amount, along with the heat transfer coefficients, is presented in the mentioned standard.

Table 6. Heat generated by metabolism of 1000 chickens during 5 rearing periods per year

\begin{tabular}{llcc}
\multicolumn{1}{c}{ Month } & \multicolumn{1}{c}{$\begin{array}{c}\text { Breeding weeks based on the pattern of 5 breeding periods } \\
\text { per year }\end{array}$} & $\begin{array}{c}\text { The average body heat } \\
\text { rate of the chicken } \\
(\mathrm{kW} \text { /period in month) }\end{array}$ & $\begin{array}{c}\text { The total heat produced } \\
\text { by the chicken body } \\
\text { during amonth }(\mathrm{MJ})\end{array}$ \\
\hline January & The first period (the first, second, third and fourth week) & 1.93 & 4669 \\
February & The first period (fifth, sixth, seventh and eighth weeks) & 8.25 & 1.27 \\
March & The second period (the first, second, third and fourth week) & 6.75 \\
April & The second period (fifth, sixth, seventh and eighth weeks) & 3.80 & 2304 \\
May & The last week of the second period and the third period (the & 4.85 & 16330 \\
June & first and second weeks) & 9.90 & 1.93 \\
July & Third period (The third, fourth, fifth and sixth weeks) & 8.25 & 11733 \\
August & Third period (Seventh and eighth weeks) & 0.75 & 11975 \\
September & Fourth period (first, second, third and fourth weeks) & Fourth period (fifth, sixth, seventh and eighth weeks) & 4.85 \\
October & Fifth period (first and second weeks) & 9.90 & 19958 \\
November & Fifth Period (Third, Fourth, Fifth, and Sixth Weeks) & 907 \\
December & Fifth Period (Seventh and Eighth Weeks) & 11733 \\
\hline
\end{tabular}

Table 7. Heat transfer coefficient of the houses

\begin{tabular}{|c|c|c|c|}
\hline Wall type & $\begin{array}{l}\text { Area } \\
m^{2}\end{array}$ & $\begin{array}{l}\text { Heat transfer coefficient } \\
\qquad w / m^{2} . k\end{array}$ & $\begin{array}{l}\text { Area } * \text { heat transfer coefficient } \\
w / k\end{array}$ \\
\hline Wall & 695.2 & 0.56 & 392.3 \\
\hline Roof & 1281.2 & 0.57 & 731.4 \\
\hline Floor & 244.0 & 1.19 & 291.5 \\
\hline Outside door & 4.0 & 5.80 & 23.2 \\
\hline Total & - & - & 1438 \\
\hline
\end{tabular}

In this part of the study, some strategies for reducing thermal energy consumption, including wall and roof insulation and underfloor heating system implementation, are discussed. In order to improve insulation, reduce the amount of thermal energy consumption and increase the level of thermal quality in the house, adding insulation to the existing roofs and creating excess insulation in the outer wall of the houses was carried out. The insulation used was polyurethane $\left(20 \mathrm{~kg} / \mathrm{m}^{3}\right)$ or rock wool $\left(40 \mathrm{~kg} / \mathrm{m}^{3}\right)$. The amount of insulation added to the roof and walls in different climates is presented in Table 8. Another method used to reduce thermal energy was the underfloor heating system. In recent years, underfloor heating systems have become very common in European countries, and the reasons for this growing expansion are the optimization of energy consumption, the distribution of heat at the surfaces and space, and the prevention of problems that other methods have. Compared to other heating systems, the underfloor (radiant) heat system, in which radiation has a large share, not only saves energy and optimizes energy consumption, but also it has many strengths in terms of comfort and thermal comfort. (Gonet et al., 2000).

Table 8 . The amount of insulation added to the roofs and walls in the different climatic conditions

\begin{tabular}{lccc}
\multicolumn{1}{c}{ Element type } & $\begin{array}{c}\text { Element width } \\
(\mathrm{mm})\end{array}$ & $\begin{array}{c}\text { Thermal resistance } \\
\left(\mathrm{m}^{2} . \mathrm{k} / \mathrm{W}\right)\end{array}$ & $\begin{array}{c}\text { Heat transfer } \\
\text { coefficient }\left(\mathrm{W} / \mathrm{m}^{2} . \mathrm{k}\right)\end{array}$ \\
\hline Insulation added to the wall in cold climates & 100 & 2.5 & 0.4 \\
Insulation added to the wall in temperate climates & 50 & 1.22 & 0.82 \\
Insulation added to the wall in dry climates & 100 & 2.5 & 0.4 \\
Insulation added to the wall in warm climates & 50 & 1.22 & 0.82 \\
\hline
\end{tabular}

The specific heat consumption $\left(\mathrm{SEC}_{\mathrm{th}}\right)$ for each period was calculated using the following formula. $\mathrm{SEC}_{\mathrm{th}}=$ Thermal energy consumption
(MJ) / Live chicken weight $(\mathrm{kg})$. Roof, wall and floor heating insulation solutions were evaluated and calculated using Carrier software (HAP). 
All analyses were performed using statistical software SPSS version 21.0 (Inc., Chicago, IL, USA), and differences between means were examined using the Duncan multiple range test of SPSS. All the results were expressed as mean and standard deviation. $P$-value of less than 0.05 was considered significant.

\section{RESULTS}

The specific heat consumption for Ardabil (representative of cold climate) is presented in
Figure 2. According to the results, all broiler farms tested in this climate had higher thermal consumption before optimization and the solutions caused a significant decrease in average heat energy consumption $(\mathrm{P}<0.05)$. Figure 3 shows the thermal energy consumption in Khuzestan, representing the warm climate. The results in the three broiler farms showed a significant decrease in thermal energy consumption after using energy-saving solutions $(\mathrm{P}<0.05)$.

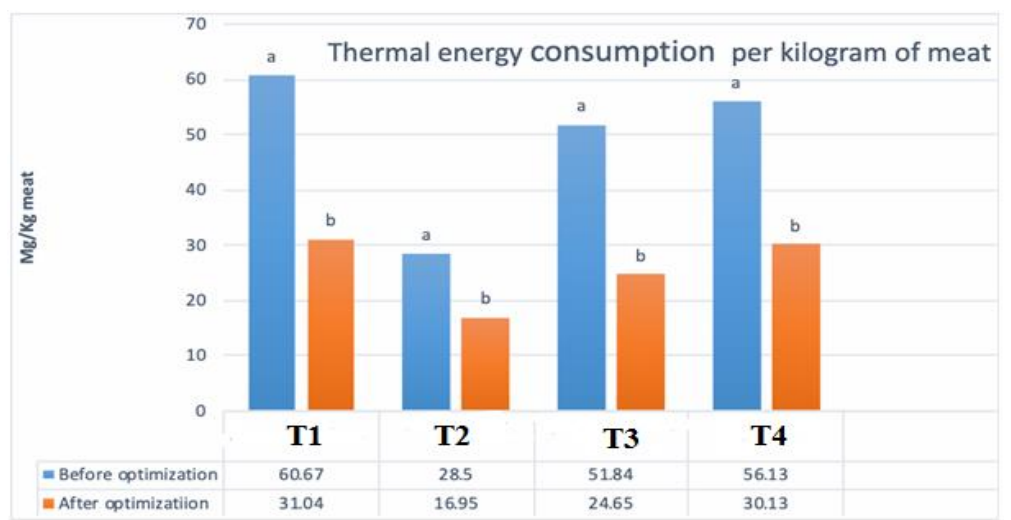

Figure 2. Thermal energy consumption in Ardabil (cold climate representative) per kilogram ofmeat before and after optimization. T1: treatment 1 (A broiler farm); T2: treatment 2 (B broiler farm); T3: treatment 3 (C broiler farm) and T4: treatment 4 (D broiler farm). ${ }^{\mathrm{a},}{ }^{\mathrm{b}}$ : The means within the each treatment with a different letter, are significantly different $(\mathrm{P}<0.05)$. All the chickens in the treatments were of Ross 308 breed.

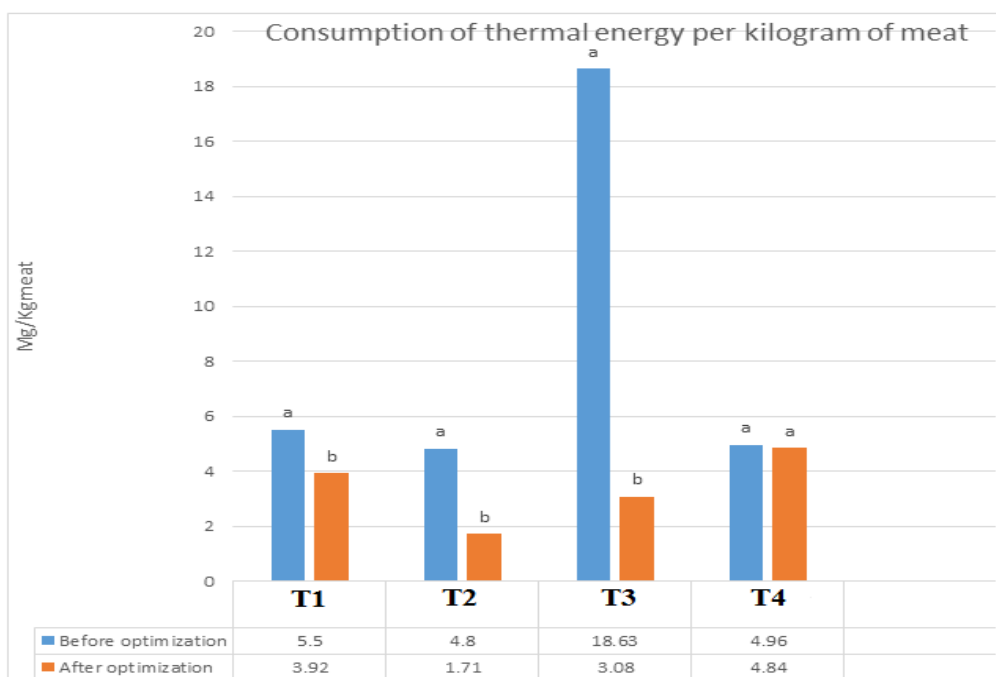

Figure 3. Thermal energy consumption in Khouzestan (warm climate representative) per kilogram ofmeat before and after optimization. T1: treatment 1 (A broiler farm); T2: treatment 2 (B broiler farm); T3:

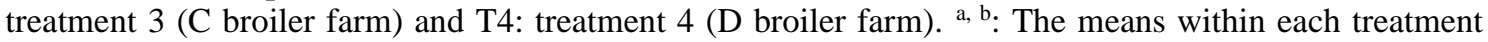
with a different letter, are significantly different $(\mathrm{P}<0.05)$. * All the chickens in the treatments were of Ross 308 breed. 
The results of comparing thermal energy consumption before and after implementing the optimizing solutions for dry climate broiler farms are presented in Figure 4. The results showed that the applied strategies resulted in significant reduction in thermal energy consumption ( $\mathrm{P}$ $<0.05)$. Figure 5 shows the results of thermal energy consumption in temperate climates. According to the results, thermal energy consumption in all the four broiler farms

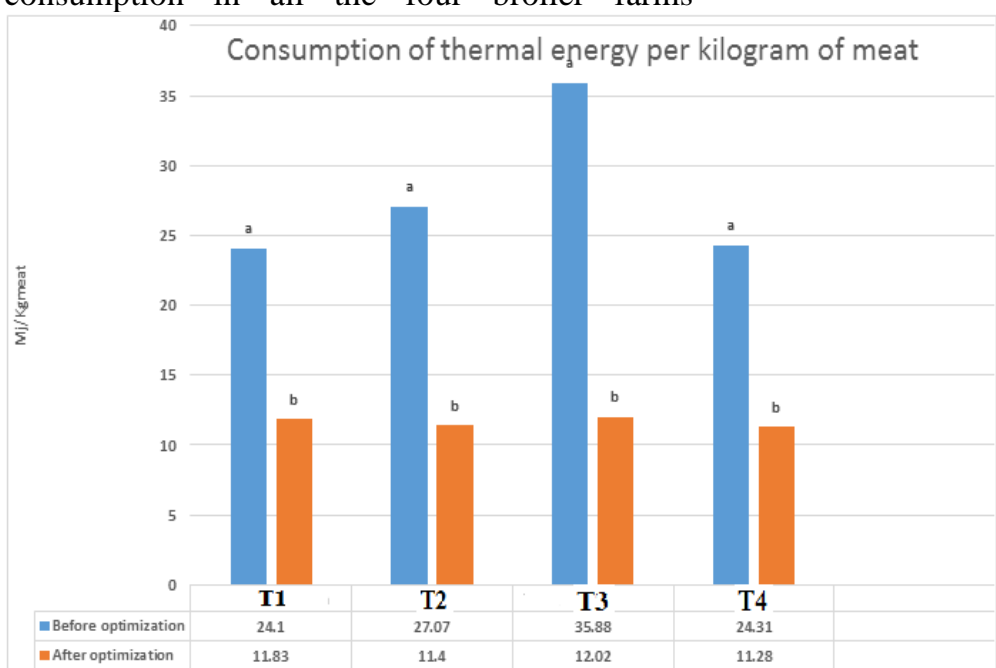

Figure 4. Thermal energy consumption in Isfahan (dry climate representative) per kilogram ofmeat before and after optimization. T1: treatment 1 (A broiler farm); T2: treatment 2 (B broiler farm); T3: treatment 3 (C broiler farm) and T4: treatment 4 (D broiler farm). ${ }^{\mathrm{a},}{ }^{\mathrm{b}}$ : Themeans within each treatment with a different letter, are significantly different $(\mathrm{P}<0.05)$. * All the chickens in the treatments were of Ross 308 breed.

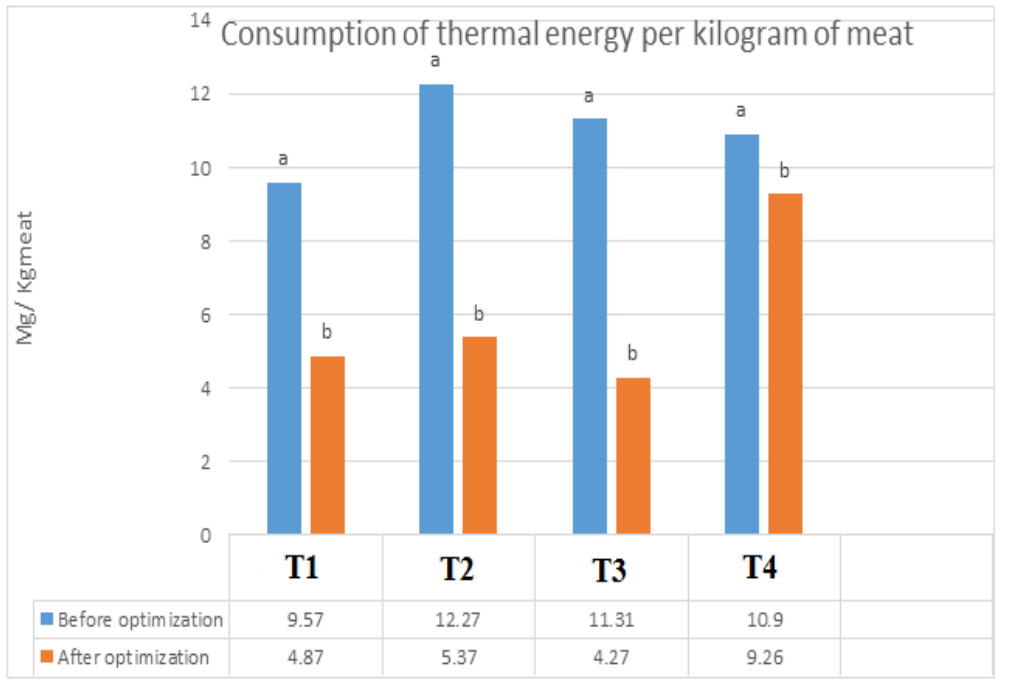

Figure 5. Thermal energy consumption in Guilan (temperate climate representative) per kilogram ofmeat before and after optimization. T1: treatment 1 (A broiler farm); T2: treatment 2 (B broiler farm); T3:

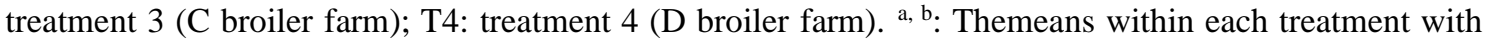
different a letter, are significantly different $(\mathrm{P}<0.05)$. $*$ All the chickens in the treatments were of Ross 308 breed. 


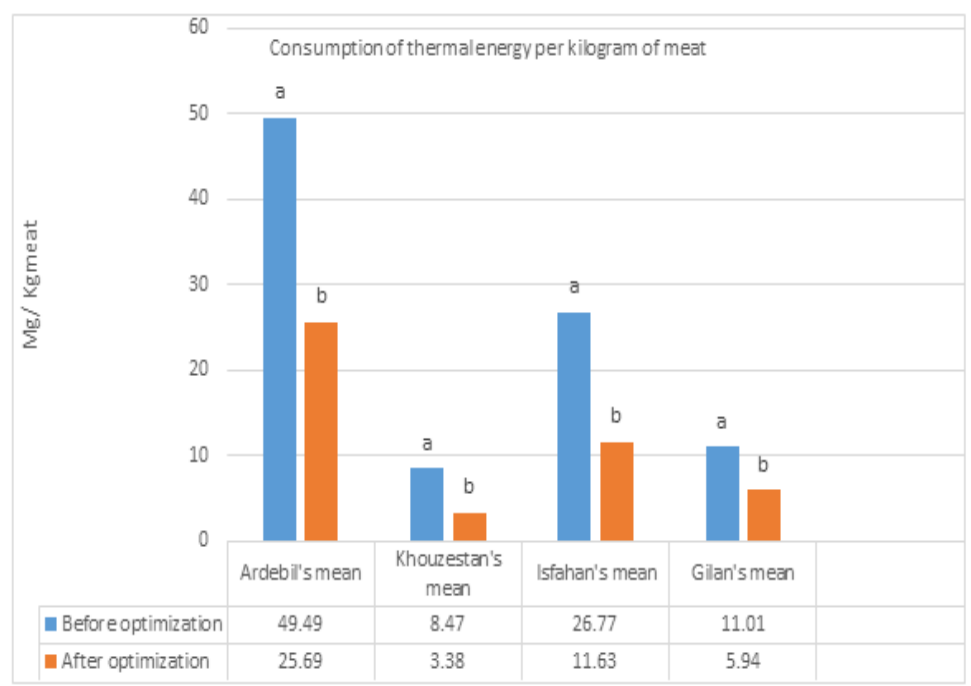

Figure 6. Comparison of average thermal energy consumption in the four climatic conditions per kilogram ofmeat before and after optimization. ${ }^{\mathrm{a}}$ b: themeans within each climate with a different letter, are significantly different $(\mathrm{P}<0.05)$.

\section{DISCUSSION}

As can be seen from the results, thermal energy consumption differs among different broiler farms in the same climate as well as among different climates, and a significant reduction in thermal energy consumption was observed when energy optimization methods were used. The results of the present study are similar to those of Dozier et al. (2006). Dozier et al. (2006) highlighted the economic importance of reducing thermal energy consumption on the growth of broiler chickens and the economic benefits of broiler farming. They concluded that houses equipped with new thermal control technologies and controlled ventilation valves would be much more efficient and profitable.

They stated that insulation of walls and roofs, proper ventilation and indoor organizing programs are essential to minimize weight differences and increase revenue for broiler breeders. They stated broiler breeders must properly organize ventilation equipment andmaintain the desired temperature. Otherwise, body weight and feed conversion ratio can be undesirable, leading to huge financial losses for the breeder.

In a study on energy consumption of broiler production units in Alborz (dry climate), it was found that diesel consumption as heat energy consumption at $43.03 \%$ was the highest consumption among inputs (Yamini Sefat $e t$ al., 2013). Some researchers have stated that the use of suitable bedding for rearing, in addition to floor insulation which is installed during the construction of poultry buildings, and the use of underfloor heating system can have a great impact on rearing and lack of air pollution with gases created from the bedding. Also, in the early days of hatching, these solutions, while creating a suitable bedding for the chickens to rest and breed, prevent the floor from freezing and heat loss from the floor of the hall, which is consistent with the results of the present experiment (Tabler, 2007; Amid et al., 2016).

According to the results, heat loss decreased after the use of solutions in cold climate broiler farms, which is consistent with the results of Baxevanou et al. (2017). Baxevanou et al. (2017) stated that, by insulating poultry halls in mountainous and cold regions, thermal energy consumption can be reduced from $180 \mathrm{~mJ} / \mathrm{m}^{2}$ to $130 \mathrm{~mJ} / \mathrm{m}^{2}$. They stated that one of the most important factors in fuel and energy consumption is adequate ventilation and optimal control of the indoor temperature system at different ages of poultry according to their needs, which is determined by the live weight of poultry. This amount of air required for poultry is about 5 to $7 \mathrm{~m}^{3}$ per hour per kilogram of live weight and, according to the hot and cold seasons of the year, with proper management of ventilation and modern insulation to permit use of the minimum required 
air in the cold season, fuel consumption can be reduced.

Rajaniemi and Ahokas (2012) evaluated the fuel consumption and energy saving potential in the poultry industry and stated that the main energy losses in this industry are due to low combustion efficiency of heating systems, inadequate air conditioning and ventilation system and no insulation of the halls in different climates. They stated that proper management of ventilation and temperature control can prevent excessive ventilation and this strategy is achievable by accurately measuring the ventilators' air discharge power in each house and creating a suitable level of aeration according to the type of ventilation (tunnel, transverse or mixed) and according to the live weight of poultry at different ages. In case of lack of management and optimization of the house, the consumed fuel and the heat generated by the ventilators will be transferred to the outside of the hall and will be wasted, and as a result it will cause thermal energy losses.

As shown in Figure 6, thermal energy consumption in cold and dry climates is much higher than in temperate and warm climates. Some researchers attribute the small difference in heat energy consumption between dry and cold climates to the fact that, in dry regions, due to the predominance of a desert climate, there are very cold nights, which increases the consumption of thermal energy in order to create the desired temperature conditions inside the breeding house (Yamini Sefat et al., 2013; Awad et al., 2017). Among the problems in broiler farming are the low performance of the thermal system and its control in farming units (Amini et al., 2015; Costantino et al., 2020). Temperature and humidity control without rearing house optimization for improved comfort and performance in different climates is costly (Costantino et al., 2018; Nabavi-Pelesaraei et al., 2013). De Vries and De Boer (2010) and Aerts et al. (2000) concluded in their studies that modern insulation of poultry walls and roofs in different climates can increase economic benefits by reducing thermal energy consumption.

\section{CONCLUSION}

The results of the present study showed that, by optimizing and modernizing equipment of poultry halls and the use of new heating systems, in all climates, energy loss and capital expenditures can be reduced as much as possible, ultimately achieving the desired profitability.

\section{REFERENCES}

ALI, M.Z.; SULTANA, S.; RAHMAN, M.T.; ISLAM, M.S. Economics of fertilitymanagement of small holding dairy farms in Bangladesh. Iran. J. Appl. Anim. Sci., v.3, Suppl.3, p,509-512, 2013.

AERTS, J.M.; BERCKMANS, D.; SAEVELS, P.; DECUYPERE, E.; BUYSE, J. Modelling the static and dynamic responses of total heat production of broiler chickens to step changes in air temperature and light intensity. Br. Poult. Sci., v.41, p.651-659, 2000.

AMID, S.; MESRI GUNDOSHMIAN, T.; SHAHGOLI, G.; RAFIEE, S. Energy use pattern and optimization of energy required for broiler production using data envelopment analysis. Inform. Proc. Agric., v.3, p.83-91, 2016.

AMINI, S.; KAZEMI, N.; MARZBAN, A. Evaluation of energy consumption and economic analysis for traditional andmodem farms of broiler production. $J$. Biol. Forum, v.7, Suppl.1, p.905-911, 2015.

AWAD, E.A.; ZULKIFLI, I.; SOLEIMANI, A.F.; ALJUOBORI, A. Effects of feedingmale and female broiler chickens on low-protein diets fortified with different dietary glycine levels under the hot and humid tropical climate. Ital. J. Anim. Sci., v.16, Suppl.3, p.453-461, 2017.

BAROTT, H.G.; FRITZ, J.C.; PRINGLE, E.M.; TITUS, H.W. Heat production and gaseousmetabolism of youngmale chickens. J. Nutr., v.15, Suppl.2, p.145$167,1938$.

BAXEVANOU, C.; FIDAROS, D.; BARTZANAS, T.; KITTAS, C. Energy consumption and energy savingmeasures in poultry. Energ. Environ. Engin., v.5, Suppl.2, p.29-36, 2017.

COSTANTINO, A.; FABRIZIO, E.; GHIGGINI, A.; BARIANI, M. Climate control in broiler houses: A thermalmodel for the calculation of the energy use and indoor environmental conditions. Energ. Build., v.169, p.110-126, 2018. 
COSTANTINO, A.; FABRIZIO, E.; VILLAGRÁ, A.; ESTELLÉS, F.; CALVET, S. The reduction of gas concentrations in broiler houses through ventilation: assessment of the thermal and electrical energy consumption. Biosyst. Engin., v.171, p.98-115, 2020.

DE VRIES, M.; DE BOER, I.J.M. Comparing environmental impacts for livestock products: a review of life cycle assessments. Livest. Sci., v.128, p.1-11, 2010.

DERIBE, B.; TAYE, M. Reproductive performance of Abergelle goats raised under traditionalmanagement systems in Sekota district, Ethiopia. Iran. J. Appl. Anim. Sci., v.4, Suppl.1, p.59-63, 2014.

DOZIER, W.A.; PURSWELL, J.L.; BARNTON, S.L. Growth responses ofmale broeiers subjected to high air veloeity for eighter twelve or twelve or twenty four hours from thirty seven to firty-one days of age. $J$. Appl. Poult. Res., v.15, p.362-366, 2006.

GHOLAMI, M.; CHAMANI, M.; SEIDAVI, A.; SADEGHI, A.A.; AMINAFSHAR, M. Effects of stocking density and environmental conditions on performance, immunity, carcase characteristics, blood constitutes, and economical parameters of cobb 500 strain broiler chickens. Ital. J. Anim. Sci., v.19, Suppl.1, p.524-535, 2020.

GONET, N.A.; SANDERCOCK, D.A.; MITCHELL, M.A. A comparison of thermoregulatory capacity in three lines of female broiler breeders. Br. Poult. Sci., v.41, p.700-701, 2000.

NABAVI-PELESARAEI, A.; SHAKER-KOOHI, S.; DEHPOUR, M.B. Modeling and optimization of energy inputs and greenhouse gas emissions for eggplant production using artificial neural network andmulti-objective genetic algorithm. Int. J. Adv. Biol. Biomed., Res., v.1, Suppl.11, p.1478-1489, 2013.

NAJAFI, S.; KHADEMOLHOSSEINI, N.; AHMADAULI, O. Investigation of energy efficiency of broiler farms in different capacitymanagement systems. Iran. J. Appl. Anim. Sci., v.15, Suppl.2, p.185-189, 2012.

OMID, M.; GHOJABEIGE, F.; DELSHAD, M.; AHMADI, H. Energy use pattern and benchmarking of selected greenhouses in Iran using data envelopment analysis. Energ. Convers. Manag., v.52, p.153-162, 2011.
POORGHASEMI, M.; CHAMANI, M.; MIRHOSSEINI, S.Z.; SADEGHI, A.A.; SEIDAVI, A. Effect of probiotic and different sources of fat on performance, carcass characteristics, intestinalmorphology and ghrelin gene expression on broiler chickens. Kafkas Univ. Vet. Fak. Derg., v.24, Suppl.2, p.169-178, 2017.

RAJANIEMI, M.; AHOKAS, J. A case study of energy consumptionmeasurement systemin broiler production. Agron. Res. Biosyst. Engin., v.1, p.195204,2012

SINGH, G.; SINGH, S.; SINGH, J. Optimization of energy inputs for wheat crop in Punjab. Energ. Convers. Manag., v.45, p.453-465, 2004.

SINGH, H.; MISHRA, D.; NAHAR, N.M. Energy use pattern in production agriculture of typical village in arid zone, India-part-I. Energ. Convers. Manag., v.43, p.2275-2286, 2002.

SPSS for Windows. Version 21.0. Chicago: SPSS Inc., 2012.

TABLER, G.T. Applied broiler research farm report: production results before and after renovation. Avian $A d v$., v.9, Suppl.4, p.4-5, 2007.

TOKLU, E.; GUNEY, M.S.; ISIK, M.; COMAKLI, O.; KAYGUSUZ, K. Energy production, consumption, policies and recent developments in Turkey. Renew. Sustain. Energ. Rev., v.14, p.11721186, 2010.

YAMINI SEFAT, M.; BORGHAEE, A.M.; BEHESHTI, B.; BAKHODA, H. Modeling energy efficiency in broiler chicken production units in Alborz province by artificial neural network (ANN) and the effect of educational level on the energy ratio. In: NATIONAL CONGRESS OF AGRICULTURAL MACHINERY ENGINEERING AND MECHANIZATION (BIOSYSTEMS). 8., 2013, Mashhad. Proceedings... Mashhad, Iran: Ferdowsi University of Mashhad, 2013. p.23-27.

YUSEF, S.A.; MALOMO, O. Technical efficiency of poultry egg production in Ogun state: a data envelopment analysis (DEA) approach. Int. J. Poult. Sci., v.6, Suppl.9, p.622-629, 2007.

ZHOU, P.; ANG, B.W.; POH, K.L. A survey of data envelopment analysis in energy and environmental studies. Eur. J. Oper. Res., v.189, p.1-18, 2008. 